\title{
Myth in Action? Figurative Images on Ceramics as a Source for Studying the Pre-Christian Beliefs of Western Slavs
}

\section{든 Kajkowski}

The spiritual culture of Western Slavs is becoming an increasingly prominent research field in archaeology. The dynamic growth of material evidence allows archaeologists not only to expand the corpus of evidence used in their work but also to formulate new hypotheses that broaden the current state of knowledge, as well as to develop new research trajectories. The study of relics of cult-places and the material remains of ritual ceremonies play a particularly significant role here. Research into material culture, including iconographic sources, is of great significance. Both these research topics can be broadened by the studies of objects commonly extracted from the earth, namely ceramic vessels. Moreover, not only the ritual behaviour that accompanies their production, or the symbolism of vessels, as such, or their forms but also about their ornamentation is of interest. Thus far, the issue of ornamentation has remained on the fringes of mainstream scholarly debates. Marek Dulinicz is among the scholars who have made the most substantial contributions to this field of research. However, since 2008, there have been no further studies on this topic. Although the corpus of completely preserved or fragmented vessels with figural depictions known today has expanded, the body of material with narrative scenes remains fairly small. New finds of vessels (or their fragments) with such imagery are found very rarely - even though numerous excavation campaigns are being undertaken - leading to the situation in which vessels with narrative scenes become rare and exceptional sources. This paper will specifically address this particular body of material. Around twenty different vessels will be considered here. Most of them are known from the area inhabited by the Baltic Slavs and the territory of modern-day Poland (Masovia and Silesia). One shard comes from Slovakia. The present paper seeks to provide answers to questions about the purpose of placing figural imagery on vessels, as well as to investigate the spatial and chronological occurrence of such finds, and the possible functions the vessels had in the everyday lives of their users.

KEYWORDS: Western Slavs, material culture, vessels, narrative depictions, mythology, religion

In studies concerning the traditional religious beliefs of the Slavs, Stanisław Urbańczyk's famous claim that this field of study brings "nothing but disappointment" is no longer valid. Even though, from time to time, some scholars are sceptical or even hypercritical, today we no longer ask if, but rather about who, how, when, and where? The main tools 
used by researchers to answer these questions are analyses of written and archaeological sources, conducted by religious scholars, cultural anthropologists, linguists, and researchers of folk culture. ${ }^{1}$ However, still neglected and underestimated is an in-depth reflection on the meaning and symbolism of imagery (which, for our needs, we can call $a r t$ ), which fully incorporate the methods developed in the broad field if iconology. It seems that the theoretical models proposed by Erwin Panofsky (1939) and his successor Rudolf Wittkower (1990) can be particularly fruitful in the studies of Slavic beliefs. Their methodology has already been applied in work on symbolic images of early medieval Western Slavs (Panfil 2002, Kajkowski, in print b) but, thus far, scholars have exclusively focused on elite material culture.

The method developed by Panofsky analyses each iconographic image/idea in a historicising approach. The basic aim of this kind of research is, primarily, to discover the internal meanings of these images, which are characterised by a certain "symbolism", and thus beyond- or even out-of-time meaning. Therefore, the method of iconological analysis consists of three stages. The first is the interpretation of individual elements of the considered image, to place its specific/individual context (which can appeal to religion, mythology, tradition, literature, politics, social relations, and similar). The second concerns the explanation of the conventional understanding of the images/scenes and determining their potential meanings (illustrative, symbolic, allegorical, and similar.). Finally, most importantly, the third stage, in which the work/image/figure/scene should be considered as a symptom of the epoch (or, as Panofsky himself sees it, a document), finding its place in archetypes and cultural history. In other words, based on the method of iconological analysis, we place an image within the frames or, rather, against the backdrop of tradition, customs, and historical events. In this way, we aim to discover the events that gave rise to the foundations of the image's creation, and thus to read the essential meanings encoded in it, which may significantly differ from the conclusions based on traditional (formal) analysis (see Panfil 2002: 18-19; Lang 2006; Davison 2009; Alloa 2015).

A similar course of reasoning is intuitively indicated by some archaeologists dealing with the analysis of (mainly antique/ancient) visual messages, often referred to as a form of communication or "expressive-affective symbolism" (Tanner 2006: 19-21). In this kind of approach, the task of art directly influences the senses and emotions or/and transmission of particular ideas or codification of specific matters. Furthermore, although we are not always able to recognise the message hidden behind them, their presence should not raise any further doubts (Bugaj 2012: 888).

Equally important for further analyses should be the acknowledgement of the fact that the actions taken by artists/craftsmen, as well as their value/aesthetic assessment can be - and most often are - a result of a meaningful development, which takes shape through the prism of magical or sacral valorisation (Kowalski 2007: 160). Unfortunately, there is no place here for a detailed discussion of the relationship between art and religion (e.g., Poniatowski 1962: 184; Zdybicka 1993: 370n; Duvignaud 2010: 218; Barrowcloug 2014:

\footnotetext{
1 About the problems, hopes, and results related to the application of these solutions, see Antosik, Łuczyński (ed.) 2020 .
} 
152; Mamzer 2018: 43-44). Let us merely note a significant argument by Cassirer and Mieletinski, who consider historical art as a form of visual expression deeply rooted in mythological narratives while simultaneously maintaining its unique character (Cassirer 1953: 98; Mieletinski 2009: 20).

Attempts to apply these cursorily presented theoretical inspirations to investigate the "model" of the spiritual culture of early medieval Slavs remain at a nascent stage. Until recently, many researchers have denied these communities not only an extensive belief system (or even mythology) but also any skills in creating visual art. This was likely the result of suppositions based on the views of Johann Gottfried Herder (1744-1803), who created the theory of Volksgeist, according to which all societies that inhabited pre-historic Europe had a specific position in the development of the Old Continent's culture. The Slavs - as a young ethnic element, entering the arena of history after the significant achievements of Frankish and other Germanic tribes occupied (in Herder's classification) the position of agrarian civilisation - in contrast to people whose development was based primarily on military activity.

As a consequence of such a way of thinking, the interpreters of Herder's thoughts denied the Slavs the ability to create epics, sublime forms of art or compositional thinking in general (Kalinowski 2016: 22). It is also likely that perpetuation of similar views may have been favoured by stereotypes seeing the beginnings of culture (including the artistic culture) in the West. There are views according to which the development of culture/art should be firstly associated with the Mediterranean world (Hellenic, Roman, Byzantine) area and then with the areas affected by Christianity. As a consequence of such thinking, the remaining areas of the known world were referred to as uncivilised or semi-civilised barbaricum (cf. Pankalla, Kośnik 2018: 24). In the mid-20 $0^{\text {th }}$ century, this line of thinking resulted in the perception of early medieval Slavs strictly as agricultural communities, and - which has important meaning to us - to the conviction that all skillfully made or decorated artefacts excavated during archaeological research (especially military equipment) represented imports or evidence of the presence of other ethnic groups on Slavic territories (cf. Abramowicz 1954: 326, 348; Gardeła, Kajkowski, Ratajczyk 2019). Some scholars even claimed that these items represented early Christian art (Kóčka-Krenz 1998: 558-559). Recent re-evaluations of all these finds demonstrate that they are most likely of local origin and the ideographic/figural motifs depicted on some of these objects have been associated with very specific pre-Christian beliefs of Western Slavs (Gardeła, Kajkowski, in print). The links of these items with the material culture of the elite are also beyond doubt.

Relatively recent records also have theories concerning the symbolical interpretations of its ideographic/figurative motifs, which are connected with the pre-Christian beliefs of Western Slavs (Gardeła, Kajkowski, in print). Its relationship with the elite culture is also not doubted. However, mythological convictions and beliefs could not be an ideological system limited to the early medieval aristocracy exclusively. They constituted the existence of the entire community. Thus, we should also, in my view, search for the signs of mythical thinking with relation to the objects that were within reach of "ordinary" people (participants of the common culture). Therefore, researchers have long been considering ceramic vessels, which represent the most common element of material culture. 
Moreover, it is not just about the ritual behaviour that accompanies their production, or the symbolism of the vessels, as such (or form/appearance), but also its ornamentation (Buko 1990: 191-198; Dalewski 1990: 19; Kowalski 2000; 2013: 36; Janowski, Kurasiński 2008; Kara 2009: 106). Among the latter, several distinct groups can be indicated: carvings at the bottoms, geometric carvings, stamps and - the subject of the present study - figural or narrative scenes. Research on this topic is not new. Twenty years ago, it drew the attention of Polish archaeologist Marek Dulinicz (2001: 86nn; 2008). Since the release of his work - apart from a short article by Thomas Kinkeldey (2008) concerning monuments of the Elbe region - narrative scenes on ceramics have never been the subject of specialised and detailed investigations.

A relatively large group of artefacts with imagery that interests us here has been found in northern Germany, an area occupied by the Polabian Slavs in the early Middle Ages. Slightly fewer of them are known from Poland. Occasionally, they are also discovered in Slovenia and Slovakia. Regrettably - with one exception - all these items are fragmentarily preserved, and the shards are sometimes very small - sometimes exceedingly so - which causes serious problems with reconstruction of the figural scenes originally placed on them, and thus also with diminishing the narrative meanings encoded within them. In this regard, certain possibilities can appear (surprisingly, generally omitted in the studies on the topic at hand), such as the context analysis of some discoveries as also comparative studies based on contemporary knowledge about figurative and visual art of early medieval western Slavs. Therefore, let us examine the available source material more closely.

From the $7^{\text {th }} / 8^{\text {th }}-9^{\text {th }}$ century settlement in Gallin in Mecklenburg (Germany) comes a fragment of the edge of the vessel with the image of a wagon. You can see here a rectangular wagon-chest (according to Wietrzichowski 1988, 148 roofed), two wheels with four spokes, shaft and most likely the back of an animal. There is also a small $X$ under the front wheel. Above the wagon, you can see four slightly wavy lines (Fig. 1). One question, in relation to the vessel form, is why the image is "upside down". It is not known either - as already noted by Dulinicz (2001: 86) - whether the drawing was made on the already finished vessel, or perhaps on its damaged fragment that was later burned-out. The latter of these possibilities could explain the reverse arrangement of the figural scene. However, taking into consideration the space on which the cross symbol is placed, there are some doubts about such an interpretation.

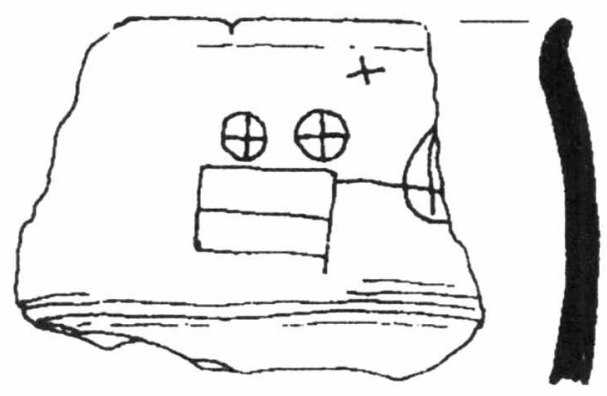

Fig. 1. Gallin, Mecklenburg, Germany. Fragment of ceramic vessel. After Dulinicz 2008: 317, ryc. 7.1.

If the presence of an X-shaped symbol on non-ceramic early medieval products still arouses discussion (cf. Kotowicz 2013), so too in the case of ceramic vessels: symbolic content is much more often allowed (including those related to traditional religious systems) (see Łęga 1929: 253; Buko 1988: 101; 2005: 334nn; Kurasiński 2018: 259). In the case of the Gallin vessel, an early chronology is possible, as the whole visual composition 
may support exactly this interpretation. So, it remains to ask what function the symbol $x$ played here? This is an important question, because it implies further analytical proceedings, in which this symbol could indicate directions of the world or have astronomical indications (Forstner 1990: 13; Brzozowska-Krajka 1994: 84). In my opinion, the oblique arrangement of the $x$ symbol in relation to the rest of the scene speaks for the second of the mentioned possibilities. I think that the intention here was to depict the sun or star. If so, at the same time, it would also confirm the desirability to place the wagon upside down. This, in turn, opens two possible ways of interpreting the entire scene. If we considered the $x$ as a celestial body, Dulinicz (2001: 86) could have been right when he saw a wagon moving through the sky here. However, if - moving after the suggestions of researchers of religious symbols - we recognise the spoked wheels as a symbol of the sun and/or a deity of uranic competences ${ }^{2}$ (Forstner 1990: 400; Szyjewski 2003: 103), then we could look here for a visualisation of the Slavic mythological narrative. It is about a (referring to the Indo-European tradition) motif, according to which the solar god has had to fight the chthonic powers. In some cases, the deity fought from a wagon, in others sitting on a horse.

Interestingly, a fragment of such a myth is also known for Western Slavs. It was transmitted unknowingly by Saxo Grammaticus, describing the Sanctuary in Arkona and more precisely, a horse belonging to Svantovit. According to the chronicler, each morning the animal was covered with foam and mud, which was supposed to be the evidence of night battles of a divine sovereign with forces opposing to him as well his followers (Saxo XIV, 39). In this sense, the $x$-sign on a Gallin vessel could be a star (Svantovit fought at night), while the wagon "driving" against the laws of nature is a deity's vehicle.

However, the possibility that the discussed vessel fragment shows a ritual procession also cannot be ruled out. The significant role of wagons in the various ritual dramas of past communities (cf. Małecki 1995) is clearly shown in written, ${ }^{3}$ archaeological, ${ }^{4}$ and iconographic sources. ${ }^{5}$ In this case, however, there are some doubts about the wagon's upside-down position, which excludes the appearance of an event in which the vehicle was pulled by an animal. However, it does not exclude the wagon's function in the rite itself. This interpretation could be indirectly supported by the information collected by ethnographers. What we find here are the descriptions of funeral customs in which, after the burial ceremony, the wagon (which takes the deceased to the cemetery) was found overturned (Fischer 1921: 145; Biegeleisen 1929: 55).

Let us add that the same sources identify souls of the dead with the stars and recall the name of the Pleiades, which are related directly to the Veles - the Slavic sovereign of the Netherworld (Gładyszowa 1960: 21nn). However - apart from the nature of these types of records - such an interpretation could not be confirmed either in archaeological sources or in medieval written accounts. Even though the wagons or its fragments and models

\footnotetext{
2 Eliade (1993: 21) believed that only understanding of the sun-wheel symbolism could enable the "discovery" of the wagon as the source of transport.

3 With the Tacitus' (I, 40) passage about the Nerthus goddess.

4 Famous Trudnholm wagon (West 2007: 373-374) or two wagons of Manse swamp in west Jutland (Glob 2004: 168).

5 With the example of Oseberg tapestry (Shenk 2002: 37).
} 
played a specific function in the ritual life of early medieval west Slavonic communities (Hołubowicz 1956: 294; Kunicka-Okuliczowa 1959: 113, 115; Kowalczyk 1968: 113), there is no evidence of any burials in wagons that could be considered distinctively Slavic. ${ }^{6}$

We have to finally consider the third option, in which the scene depicted on the Gallin shard has no relation to religious life. Could the wagon placed here illustrate any element of everyday life? By adopting such a solution, we should expect a mapping of the real situation, meaning one in which the cart should not be turned upside down, because it is difficult to imagine people or goods being transported in this way. Thus, in my opinion, the scene shown on the Gallin shard should be associated with the spiritual culture of the Baltic Slavs.

The extensive figural motif has also been preserved on four small fragments of the vessel found on the fortified settlement, dating back to the $9^{\text {th }}-10^{\text {th }}$ century, in Repten on the border of Brandenburg and Lusatia (Lkr. Oberspreewald-Lausitz, Germany). There is a scene depicting four animals and one human figure, probably holding a bow. The possibility that originally there was a figure of a man depicted on one of the animals cannot be excluded (Dulinicz 2001: 86; Kinkeldey 2008: 497). (Fig. 2) Thus far, the most prominent hypothesis interprets the whole scene in a military aspect. Less often, it indicates hunting for wild animals or capturing horses (Kinkeldey 2008: 499-500). Researchers' attention is also given to abstract imagery, which - I think - has recently gained quite good support. I am referring to the discoveries in the area of the former stronghold in Dąbrówka (Greater Poland). This stronghold dates back to the $9^{\text {th }}$ century and the first half of the $10^{\text {th }}$ century, so it functioned at the same time as the object in Repten (Kinkeldey 2008: 497).

A similar chronology is not the only aspect that attracts our attention. Essential to these considerations is one of the finds within the relics of one of the buildings (no. 29) in Dąbrówka. It is the bottom of the ceramic vessel decorated with an ornament that reveals common features to the Repten figural scene (Pawlak, Pawlak 2019a: 249). (Fig. 3) Significantly, object 29 is supposed to be an element of a larger ceremonial structure and, in addition to the mentioned vessel fragment, there were other shards decorated with isosceles crosses and a swastika motif. Human bones were also here (Pawlak, Pawlak 2019b: 168). Therefore, it is quite likely that all remains excavated at Dąbrówka may indicate their relationship with ritual activity. Consequently, it is possible to hypothesise that it is no accident that vessels decorated with religious symbols were found here. In connection with this assumption, a similar meaning can be combined with the mentioned alleged figural image. What then could the Repten/Dąbrówka narratives deal with? Before we attempt to answer this question, let us pay attention to a detail, specifically to zoomorphic characters. For scholars, it is difficult to recognise, however, why two of the horses are clearly drawn smaller than the others? If it was not about the space perspective (which should be considered unique, not to say atypical, ornamentation), or having to show adult horses with foals (Kinkeldey 2008: 498), the goal of this could be to show not the same, but different animal species. If so, it is possible to recognise the smaller figures as a depiction

\footnotetext{
6 This is, moreover, a broader problem that should be considered as a custom related to elites, not necessarily connected with the "ethnic differentiator".
} 
of dogs? Taking this interpretation for a moment - and following the hypothesis proposed by Felix Biermann (2000: 262) - let us note that the scene on the Repten vessel (and probably also Dąbrówka) could be surprisingly coincident with everything we know about beliefs focusing on the plot about the so-called Wild Hunt (Wilden Jagd). ${ }^{7}$ The main actor of the myth is a supernatural being (often a chthonic one), sitting on horseback, accompanied by (moving on horse or on foot) fallen warriors (or their shadows/souls) and other out-of-this-world or mediating creatures - mainly horses and dogs (Czerny 1896: 68; Dźwigoł 2004: 157; Bonowska 2008: 50; Kropej 2008: 188-191). According to current interpretations, the Wild Hunt motif should be related to former beliefs connected to fertility and renewal to nature (Kropej 2012: 52), or ritual activities related to the band of warriors who formed a cult groups bound by common beliefs (Pollington 2013: 110). The latter could be attractive because, both in Repten and in Dąbrówka, there are remains indicating the presence of militarised elites. However, Dąbrówka excavations revealed traces of ritual activity (animal skeletons and plant remains) perhaps connected to fertility and renewal (Pawlak, Pawlak 2019b: 169).

It is hard to judge whether an archer-figure preserved on the vessel fragment from Sternberg (Mecklenburg, Germany) could be a part of the analogous narrative scene as depicted in the case of Repten. The find comes from a settlement dated to the $7^{\text {th }} / 8^{\text {th }}-9^{\text {th }}$ century. The character is incomplete. What we can observe is the head and a fragment of the bow with the cord and an arrow. The preserved composition indicates that originally the weapon was in the hands of the anthropomorphic figure (Dulinicz 2008: 315-316). (Fig. 4) Unfortunately, the condition of the drawing does not provide any

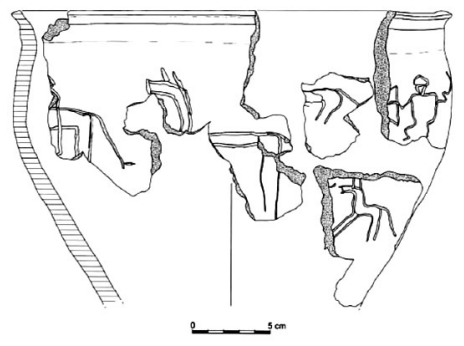

Fig. 2. Repten. Lkr. OberspreewaldLausitz, Germany. Fragment of ceramic vessel. After Kinkeldey 2008: 498. Abb. 1:a.

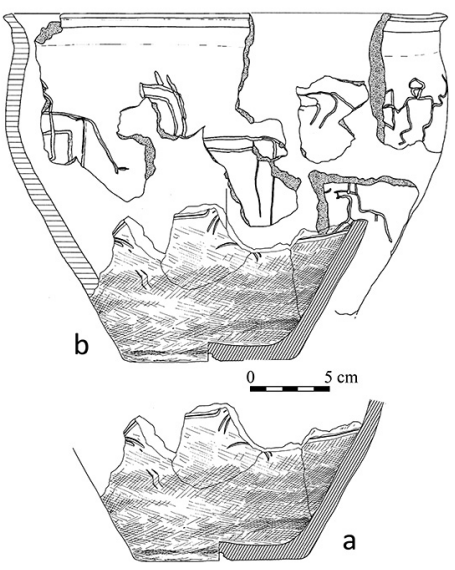

Fig. 3. Fragments of pots: a) Dą̧brówka, wielkopolskie voivodeship, Poland; b) Comaprison of Dąbrówka and Repten shards. A kind permission of Ewa and Paweł Pawlak.

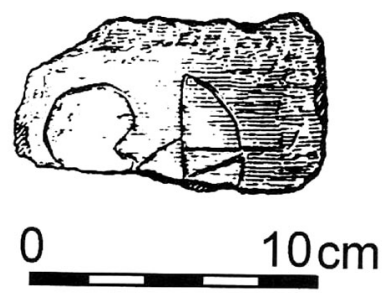

Fig. 4. Sternberg. Lkr. Ludwigslust-Parchim. Fragment of ceramic vessel. After Dulinicz 2008: 316, ryc. 5.1 .

\footnotetext{
7 Even if the genesis of this mythical story is derived from the world of Germanic tribes (Czerny 1896: 67; Czarnowski 1956: 186), its presence in folklore among Western Slavs, suggests that it could be adapted quite quickly by these societies. If we recognize that this tale is present on the 8th or 9th century Slavic vessels, then it can be assumed that Slavs became acquainted with them in the earliest stages of the Middle Ages or even during the migration period. However, these are presuppositions requiring more detailed studies.
} 
grounds to state whether it was originally shown on foot or mounted. Therefore, it is difficult to find further similarities with the engraving on Repten shards.

Most likely, the schematically marked figure of the rider is depicted on a fragment of the $11^{\text {th }}$-century vessels excavated in Gdansk (pomorskie voivodeship, Poland) (Lepówna 1959: table 1: a). (Fig. 5) It is extremely interesting and rare that it was placed at the bottom of this vessel. Although, as already stated, some of the signs placed on this part of ceramic products could be combined with symbolic meanings; whether such significance was attributed to this bottom-shard is not known. Any further interpretation is not only hindered by the place of the image (invisible when using the vessel), but also no other fragments of it (on which further elements of a possible narrative scene would be visible), the lack of analogies, and the absence of any elements accompanying the rider. Consequently, we are unable to go beyond the frame of speculations.

More fortunately, an additional narrative elements accompany the rider from the vessel of Polabian Wessentin (Kr. Müritz, Germany). The find comes from an open settlement area dated to the $7^{\text {th }} / 8^{\text {th }}-9^{\text {th }}$ century. The depicted scene shows a man sitting on horseback, who is disclosed in a dynamic arrangement, suggesting movement. The impression of movement is also enhanced by the clearly marked bridle. Behind the rider, there is a group of vertical parallel lines engraved, and there is a serpentine-like line/shape before the horse. Above the figure, there is a horizontal, double engraved line. (Fig. 6) In current literature, various attempts have been made to interpret these drawing details, and thus the scene as a whole.

The vertical elements depicted behind the horse are considered to be a fence, a line of trees or a row of spears (Dulinicz 2008: 314; Łukaszyk 2012: 141), a double line above the

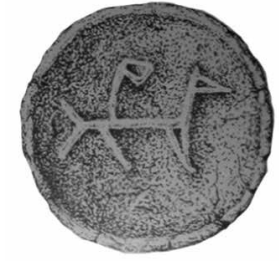

Fig. 5. Gdańsk. Pomorskie voivodeship, Poland. Bottom part of ceramic vessel. After Lepówna 1968: cover artwork.

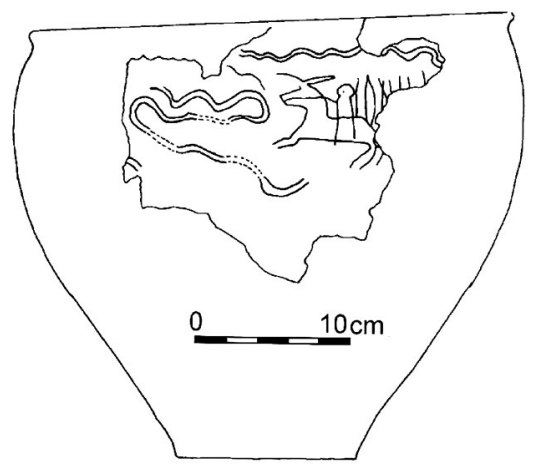

Fig 6. Wessentin. Kr. Müritz, Germany. Fragment of ceramic vessel. After Dulinicz 2008: 313, ryc. 3.1 .

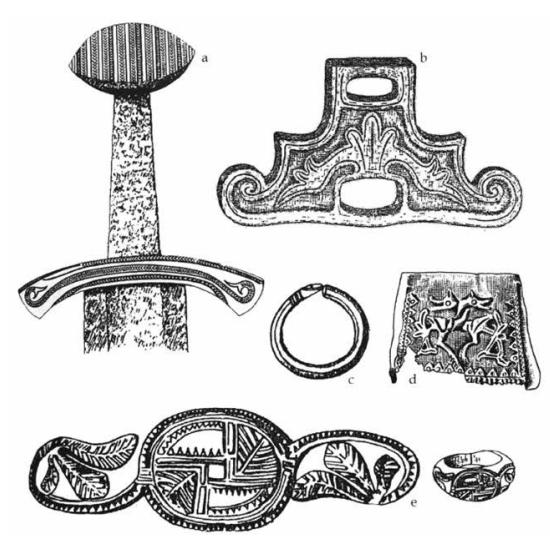

Fig 7. Snake/dragon motifs on West Slavic artefacts, a) sword from Pokrzywnica Wielka. Warmińsko-mazurskie voivodeship, Poland; b) copper-alloy bar bit from Lutomiersk. Łódzkie voivodeship, Poland; c) silver bracelet. Poland; d) silver/copper-alloy kaptorga from Biskupin. Kujawsko-pomorskie voivodeship, Poland; e) silver ring from Brześć Kujawski. Kujawskopomorskie voivodeship, Poland. After Gardeła, Kajkowski, in print. 
rider to be the sky-vault and the sinuous double line in front as a river or road (Wietrzichowski 1990: 59; Dulinicz 2008: 314; Kinkeldey 2008: 498) or snake/dragon figure (Szczepanik 2015: 187). Consequently, the scene itself is interpreted as a kind of map (Dulinicz 2001: 85), or as a visualisation of mythical narrative showing "a deity in action" (Dulinicz 2008: 314). This mythological interpretation is of particular importance. Adopting this line of reasoning, we can suppose that the scene could be a visualisation of the cosmogonic myth: more specifically, the part about the struggle of the thunder god against the chthonic serpent/dragon (Slavic Żmij) (Szczepanik 2015: 187-188). Although this character appears on other West Slavic artefacts/objects (cf. Gardeła, Kajkowski, Söderberg 2019), in this case, this interpretation is not truly convincing. It can be refuted by at least four arguments.

The first can be related to the rider figure. If he were to imagine a thunderer fighting a foe, then we should expect him to have some weapons or the weapon would be symbolically imagined here (e.g., as a zigzag/lightning, which is present on other ceramic vessels).

The second problem concerns the alleged spears depicted behind the rider. If three of them are placed directly on the right side of the horse, there are no warrior-figures that could hold them. In this case, however, we can conditionally allow a solution that the rider and his horse were shown in supernatural size. In iconological patterns, it would indicate the "inhumanity" of the rider, which could also be an explanation of why the sky-vault is placed just above the horseman's head.

A third doubt concerns the alleged snake/dragon being, which has no anatomical details that would confirm this point of identification (in contrast to a horse or rider, who even has an eye indicating a direction of observation). The detail also has no analogies in Western Slavs' figural art (Fig. 7). Even the most schematic images of snake/Żmij do not resemble the shape shown on the Wessentin shards.

In addition, it is noteworthy that the two lines in front of the "snake" suggest that, in the further perspective of the scene, it could be an analogous serpentine shape. This shape should be surely considered as a later landscape element. It could also be something completely different: something that could radically change the picture of the situation and the sense of the scene at all. We have to remember that we see just a small part of the whole. Thus, in building further interpretations, we are doomed to a large dose of subjectivity. However, in the context of the problems raised here, we have to consider whether the contents that the analysed scene could have been coded.

If we consider the lines behind the horse to be armaments wielded by "human" warriors and the meandering shape in front of them to be a river, then (based on what was said above) the narrative could relate to a Wild Hunt story. However, if we consider the "monstrous" interpretation of the rider to go too far, we can indicate one more possibility. It could relate to pre-Christian eschatology and illustrate the journey to the Netherworld. In such a way (on horseback and/or crossing the river/water), the Slavs imagined a way to the land of the dead (Bylina 1993: 80; Cooper 1998: 114; Masłowska, Niebrzegowska 1999: 325).

This way of interpretation may, however, find interesting exemplification in the case of another vessel that was discovered in 1939 in Chróścino (opolskie voivodeship, Poland). 
It was excavated by the road leading to a crossing area of the Odra River. There was a pit discovered (not necessarily referred to as a grave) where a human skull was placed next to the vessel. It is even more intriguing because a triangular hole was observed at the bottom of the skull. According to some researchers, the hole was evidence that originally the head of the dead was stuffed with a stake/spear (Wachowski 1975: 46; Limisiewicz 2002: 358). Regardless of the validity of these hypotheses, the context of discovery allows connecting it with the manifestations of thinking in an abstract manner.

The excavated, well-preserved vessel was decorated with a row of oblique punctures. Below there is carving of a horse, which is covered with the lines running around the pot (Fig. 8). The whole composition gives the impression of an intention to show an animal moving behind some obstacle - perhaps transparent since the whole animal is visible to the observer. In this context, it is worth paying attention to the suggestions for reading other motifs present on the analysed artefact: horizontal rows of wavy lines (often appearing on Slavic vessels), which are sometimes considered to be related to aquatic imaginations (Chudziak 2015: 31; Woźny 2017: 30). Although on the Chróścino pot there are straight lines, so the dynamic layout of drawing and a (marked with diagonal lines) river bank (?) could - in my opinion - reflect the characteristics of flowing water. In relation to this interpretation, how the animal figure is placed is noteworthy. The horse figure is placed across the vessel, in a vertical arrangement (in relation to the standing container). Therefore, the arrangement of the whole scene seems to reflect the mediation properties of horses in the religious conceptions of pagan Slavs.

Let us return to the images of the riders for a moment. Such a character appears on yet another vessel shard found in Poland. The artefact comes from an open settlement, in the outskirts of the Wyszogród (mazowieckie voivodeship) stronghold, and was in use between the $7^{\text {th }}$ and $8^{\text {th }}$ centuries (Fig. 9). It was discovered in a pit situated between the relics of two buildings (dugouts). ${ }^{8}$ One of the preserved fragments of a vessel shows a well-preserved figural engraving with a mounted figure riding a quadruped; the animal is depicted in a manner that does not allow a clear description of its species. If the anatomical details on the animal's head may suggest antlers (a deer?), the anthropomorphic figure depicted on its back, indicates it is a riding animal, which can only be a horse in the early Middle Ages. ${ }^{9}$ The pose in which the anthropomorphic form is presented is not entirely clear. It is difficult to determine whether it is a sitting or standing (on horseback) figure. We also do not know whether the character has been depicted without head or the head was covered by lightning. ${ }^{10}$ The whole composition was considered by the discoverers to

\footnotetext{
8 Next to it was a second vessel decorated with a cross symbol at the bottom-part.

9 This, of course, cannot prejudice the matter, especially if we consider the possibility of mythological themes here. However, in this case, horses could play the first role too (what could be based on the already mentioned relation of Saxo Grammaticus about Svantovit's night expeditions).

${ }^{10}$ In such a way (as a lightning, relatively including rainstorm; see Jelenski, Piatkov, Liybimtsev 2015: 69) three zigzag lines above the rider are interpreted (Szymański, Moszczyński 1988; Dulinicz 2008: 91). Ornamental motifs in the form of zigzag lines are known from several other shards (Bosau-Möhlenkamp, Fahrenhorst, Grimmen, Gross Strömkendorf, Lissa; see Dulinicz 2001: 87; 2008: 312). Unfortunately, the fragmentarily preserved decorations does not allow going beyond an assumption that originally they could have been a part of more complex narrative scenes (similar to the Wyszogród depictions)
} 
represent the thunderer holding a lightning bolt (i.e., Perun) (Szymański, Moszczyński 1988; Pleterski 2014: 315). However, we can look at this scene differently: it seems that the anthropomorphic figure depicted here is not holding the lightning but has been struck by it, which would explain the way it was expressed on the animal's back. The dynamics of such a narrative could reflect the moment of knocking the rider down. If so, it could be a visualisation of the cosmogonic myth, and more precisely the moment of defeating the chthonic deity.

In this context, we should go back to the identification of the animal species. A second way of interpretation, indicating a horned animal (probably a deer), finds quite good support in results of research on animal symbolism. These statements confirm the strong bonds of deer with sacrum, where it played not only the function of mediator but was also a pluvial being associated with vitality, reproduction and rebirth of nature (Forstner 1990: 267-268; Mikoś 1997: 181). The matter becomes even more interesting if we note that, in Indo-European tradition, a deer was also associated with the world of the dead (performing a role of a conductor of souls) (Eliade 2002: 141) or guardian of cattle herds (identified with the spirits of the dead in the Slavic eschatology) (cf. Gardeła, Kajkowski, Ratajczyk 2019).

A similar scene may have been on another part of a clay pot, this time from Polabian Rerik (Kr. Bad Doberman, Germany). The shard comes from an open settlement area dated back to the $6^{\text {th }} / 7^{\text {th }}-8^{\text {th }}$ centuries. There is a figure of an animal with an unnaturally long neck (with a mane?) and a pointed, flat muzzle. The animal has a very emphasised and tight chest; the tail is also marked. Above it, there are horizontal lines (sky?), from which vertical zigzag and split lines (lightning?) depart (Dulinicz 2008: 315) (Fig. 10).

According to Kinkeldey (2008: 498), poorly preserved lines carved over the quadruped show the rider. It is difficult to determine whether the

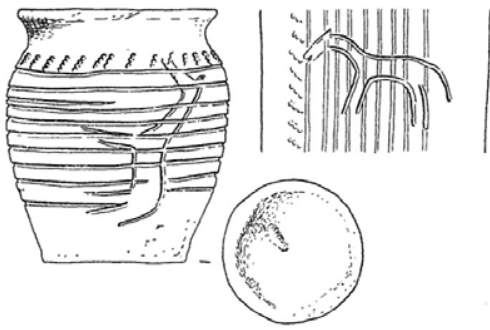

Fig. 8. Chróścino. Opolskie voivodeship, Poland. Ceramic vessel. After Wachowski 1975: 80.
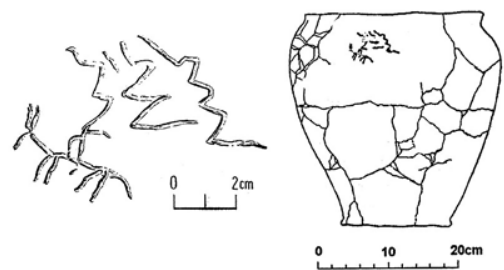

Fig. 9. Wyszogród. Mazowieckie voivodeship, Poland. Fragments of the pot. After Dulinicz, Moszczyński 2013: 63. Abb. 18.

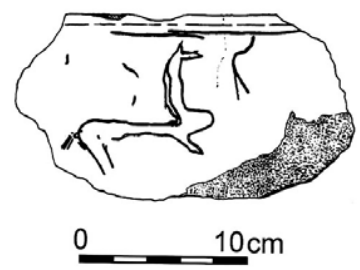

Fig. 10. Rerik. Kr. Bad Doberman, Germany. Fragment of ceramic vessel. After Dulinicz 2008: 315 , ryc. 3.4 .

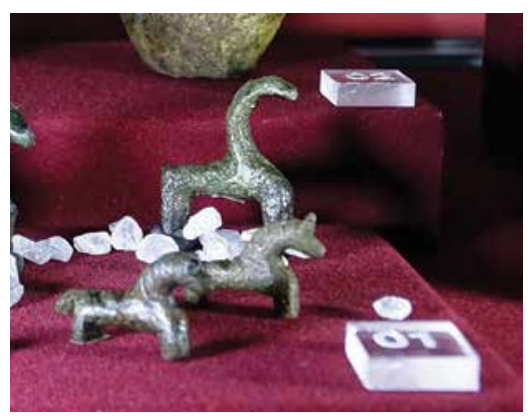

Fig. 11. Giecz. Wielkopolskie, voivodeship, Poland. A zoomorphic figure. After http://www. lucivo.pl/2010/05/wykopaliska-2008-2009. html. Access: 2020-04-19. 
German researcher assessed this element correctly. However, more attention should be paid to the zoomorphic figure depicted here, because it seems to show an abstract image. This, in turn, raises the question of the author's intention. Was it to draw a being that we would call "fantastic" today? Before we attempt to answer this question, let us pay attention to "physical" features of the full-plastic, made of non-ferrous metals, figurines interpreted as horses. ${ }^{11}$ If, in most cases, such identification raises no doubts, there are a few of them that differ from

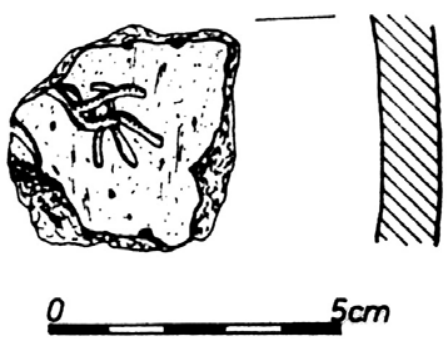

Fig. 12. Dębczyno. Pomorskie voivodeship, Poland. Fragment of ceramic vessel. After Sikorski 1991: 284, ryc. 3.1. realistic-made specimens. It is extremely interesting they have a long, curved neck, pointed and flat muzzle and a prominent breast (Fig. 11). If it is not an issue of a lack of skills or production mistakes, then we should ask whether "physical" features marked in this way should be taken as a clue to the species identification of these animals? If we accept this way of thinking, we must assume that these features are distinctive. It is difficult to attribute them as to the horses as well as to other species of fauna known at early Middle Ages. It could be, however, an animal inhabiting then imagination or/and connected to another (i.e., mythical) world. Such a solution would be extremely attractive, but due to the lack of more detailed research on this topic, it cannot be included in further discussion. ${ }^{12}$

According to Andrzej Sikorski (1991), the figure of the rider may have been originally placed on the vessel excavated in relics of building in Dębczyno (pomorskie voivodeship, Poland) (Fig. 12). The building was a residential element located within an open settlement area from the $6^{\text {th }}-7^{\text {th }}$ centuries. In the opinion of this Polish archaeologist, there are two legs and long tail preserved on the shard. Unfortunately, too small a fragment of the vessel has survived, which is why we are not able to justify and consider the proposed lead. Thus, Sikorski's guesses must remain in the realm of hypotheses difficult to verify.

Doubts about the animal identification could also apply the zoomorphic figure originally depicted on the vessel from Presenchen stronghold (Lkr. Dahme-Spreewald, Germany) (Kinkeldey 2008: 499). The details of the drawing do not indicate whether the quadruped should be considered a horse or deer. Similar doubts apply to two figures on the shard excavated at Stargard Gubiśki (lubuskie voivodeship, Poland) (Biermann 2000: 262) (Fig. 13).

The image of animals is present on a partly preserved depiction on the vessel from Podebłocie (mazowickie voivodeship, Poland) (Fig. 14). It was found within the relics of residential building (no. 10) excavated on the stronghold from the $7^{\text {th }} / 8^{\text {th }}-9^{\text {th }}$ centuries. The upper part of the vessel is covered by an ornament in the form of lines forming a circular shape interpreted as an image of the sun. Underneath and above it is a row of parallel and vertical lines. The lower part of the pot is decorated with two parallel rows of horizontal lines. For us, the most interesting is the first of the mentioned lines contexture, which is interpreted as a "line [group] of zoomorphic images, horned animals"

\footnotetext{
11 Associated with the spiritual life of the early medieval Western Slavs (Kajkowski 2019: 185nn).

${ }^{12}$ It is part of a separate studies undertaken by author and Dr Leszek Gardeła from The National Museum of Denmark
} 
(Barford, Marczak 1992: 130). Unfortunately, the originators of this interpretation did not explain what prompted them to such a view, and it seems this is too loose an attempt to give the sense to the form. Regardless, it does not change the fact that we are dealing with a narrative form here perhaps associated with solar/pluvial concepts. However, its primal sense is impossible to read. ${ }^{13}$

According to some researchers, the fragmentally preserved zoomorphic image (part of the neck, torso, forelegs) with horns could be placed on the second ceramic shard discovered in Pomeranian Dębczyno (Fig. 15). Martin Planert (2012: 316) believes that it is an image of a cattle turned (running) to the right. However, this interpretation seems to undermine two details: different from other (above-mentioned) zoomorphic figures, the limbs are not depicted realistically, and there is an element located above the animal (?) made using the of smudging technique. Sikorski (1991) sees it as the wing, and the whole depiction shows an animal; if so, it could only be a schematically represented animal of a fantastic nature.

There is much less doubt regarding the identification of a quadruped imagined on a shard from the $12^{\text {th }}$-century layers of Wolin (zachodniopomorskie voivodeship, Poland). A detailed designation of the animal's features allows it to be considered a deer (Łuka 1973: 32; Filipowiak 1993: 32; Dulinicz 2001: 87) (Fig 16). This image is usually connected to symbolic/mythological ideas and associated with eschatology (Luka 1973: 32), fertility (Hensel 1984: 111-112), or cult as understood generally (Filipowiak 1993: 34).
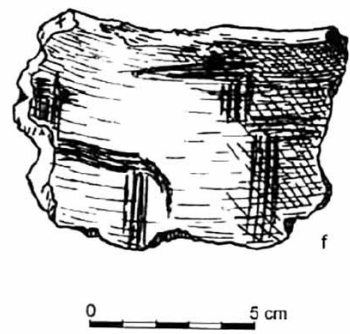

Fig. 13. Stargard Gubiśki. Lubuskie voivodeship, Poland. Fragment of ceramic vessel. After Kinkeldey 2008: 499, Abb. 2 f.

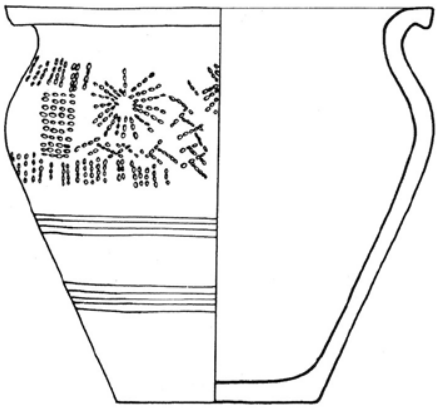

Fig. 14. Podebłocie. Mazowieckie voivodeship, Poland. Fragment of ceramic vessel. After Barford, Marczak 1992: 130, ryc. 6.2 .
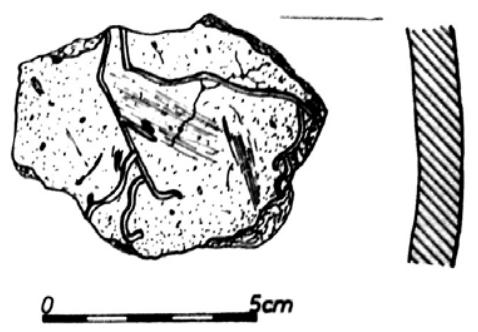

Fig. 15. Dębczyno. Pomorskie voivodeship, Poland. Fragment of ceramic vessel. After Sikorski 1991: 284, ryc. 3.2 .

\footnotetext{
${ }^{13}$ I find unlikely the hypothesis which connects this decorating patterns with Carolingian influences. I am also sceptical about suggestions pointing the Christian resurrection symbolism behind these ornamentations (Buko 2016: 18-19). This hypothesis, as it might be suspected, was formulated as a support for another one, i.e., concerned characters placed on (dated to $9^{\text {th }}$ century) famous Podebłocie tablets. There are many scholars who consider signs engraved on its surface to be written in the Greek alphabet, abbreviations of holy names and the proclamation "Jesus Christ wins". Thus considers them to be an important argument indicating the early reception of Christianity in the "Polish" lands (see Kollinger 2014: 398-399). Apart from the fact that this problem is still far from being resolved, one should agree with doubts indicating that "on this basis, no far-reaching conclusions can be drawn [especially] in the cultural and religious context" (Polek 2017: 42).
} 
If images of animals on West Slavic ceramics are extremely rare, the avifauna representations are unique. One of them seems particularly interesting for the problems studied here. It is depicted on the upper part of a large vessel (and probably one more yet; see Messal 2001: 349, Abb. 4; 350, Abb. 6), discovered during archaeological research of the Glienke stronghold (Kr. Mecklenburg-Vorpommern, Germany) (Messal 2015: 84nn) (Fig. 17). The ornament of our interest consists of threads of alternately placed swastikas and stylised figures of birds with strongly accented, curved beaks. In studies on animal symbolism, the full-sized or engraved figures of birds most often are referred to two meanings: eschatological and cosmological. ${ }^{14}$ The first of these is expressed by the belief in the role of birds in the idea of metempsychosis. They were here an embodiment of the dead themselves, or a mediation being allowing reach the realm of Otherworld (cf. Szyjewski 2003: 195; Aldhouse Green 2005: 145; Waida 2005: 947). ${ }^{15}$ I think that it is quite likely that this is what the creator of the vessel and/or depiction of Glienke vessel wanted to show. Such a way of interpretation may be suggested by two details. One of them is a manner by which both figural motifs are shown. If the birds depict specified narrative and symbolic matters, and the swastika plays the role of the solar disc, the arranging of both these elements in one line and perspective may suggest a semantic relationship between

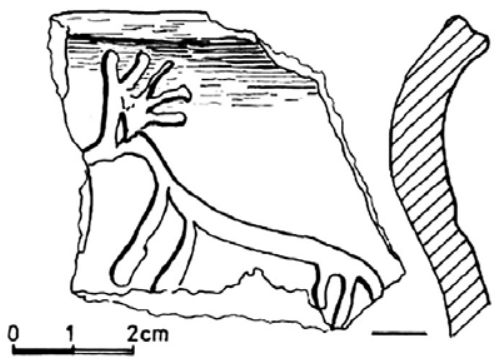

Fig. 16. Wolin. Zachodniopomorskie voivodeship, Poland. Fragment of ceramic vessel. After Buko 1990: 138, ryc. 63b.

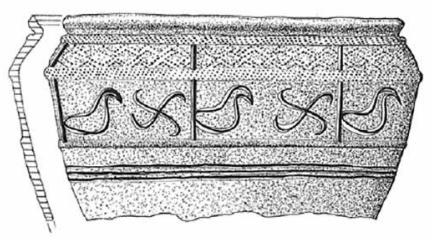

Fig. 17. Glienke. Kr. MecklenburgVorpommern, Germany. Fragment of ceramic vessel. After Messal 2015: Taf. 78.2.

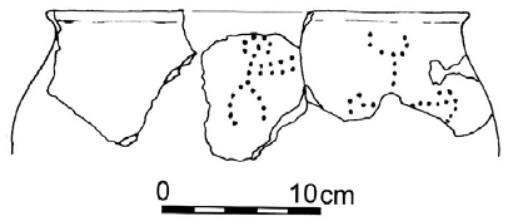

Fig. 18. Schulzendorf. Lkr. Dahme-Spreewald, Germany. Fragment of ceramic vessel. After Gustavs 1979: 282, ryc. 4a. them, the meaning of which could, in turn, be indicated by another decorative detail - a triple line under the entire scene. If we examine the other figural engravings analysed above, we will see that an identical (triple-) or similar (double line) motif in the context of entire narrative depictions symbolically designate (or can designate) the vault of the heavens. If we view the lines of Glienke vessel this way, this vault would be below the

\footnotetext{
${ }^{14}$ However, it should be noted the opinions according to which a small number of avifauna images on Slavic artefacts is a proof of small or even any role of these animals in the spiritual life of this communities (Messal 2015: 92). Nevertheless, the set of such items is not as small as it seems to be. Moreover, the context of some discoveries and/or ideographic programme placed on their surface give foundations to consider specific functions of birds in religious life of early medieval Slavs (cf. Müller, Müller-Muči 1998: 58; Vańa 1999; Kajkowski 2019).

${ }^{15}$ It was known also to Christian medieval literature and art (Schmitt 2002: 180; Waida 2005: 949).
} 
entire scene. This, in turn, could indicate that the craftsman intended to show the events taking place "in the heavens" (?) -beyond the realm at which the souls of at least some of them could aim.

However, a detail complicating the matter appears here. If we look at the ornamentation of other shards again, we will see that there is a more realistic and easier-to-identify image of the solar disk. It has the form of a circle-shaped object with lines radiating its centre. Another detail that draws attention is the way the birds are shown: most commonly floating. This finds good analogies in other images and the figural art of Western Slavs. In some cases, they are a part of extensive ideographic topics, which could be derived from mytho-cosmological narratives (Gardeła, Kajkowski, Ratajczyk 2019). Based research results to de, both of proposed solutions seem acceptable.

Leaving the animal world for a moment, let us consider these ornamental motifs, for which the main narrative axis is a character of anthropomorphic attributes. A fragment of a vessel from Schulzendorf (Lkr. Dahme-Spreewald, Germany) was found in one of the resource pits excavated in the open-settlement site dated to the $8^{\text {th }}-9^{\text {th }}$ centuries (Gustavs 1979: 282). The fragment is decorated with two figural elements ${ }^{16}$ (Fig. 18). The first one, not causing significant identification problems, is the human figure pictured with his hands directed towards the second, harder-to-interpret image. Thus far, there have two suggestions of its interpretation: as a boat (in profile) or wagon (horizontal projection from above). Thus, the whole narrative, because of the human figure's adoration gesture, is interpreted as a ritual performance ("the cultic event", literally) (Gustavs 1979: 285nn; Kinkedley 2008: 499). Taking this approach, both attempts to identify the object next to the human figure offer interesting possibilities, which we became acquainted with by analysing the carvings on the Gallin vessel. Two options are under consideration: one characterised the whole scene as a "ritual procession", while the other characterised it as a picture of a funeral drama. The latter interpretation, I think, could explain the presence of a boat image here: a vehicle, which among the elite members of early medieval coastal communities - including Slavic ones - fulfilled a certain function in funeral rituals (Kajkowski 2016).

Two human figures are also present in a miniature vessel from Radzim (Greater Poland). It was excavated on the stronghold located on the river island (on the Warta River). Unfortunately, no more detailed information on the exact location of the vessel has remained. The chronology of the stronghold dated between the $9^{\text {th }}$ and $14^{\text {th }}$ centuries (Jasnosz 1982-1984: 85-86) is also poor. The entire surface of the vessel is decorated with horizontal lines, whereas on the upper part of the container, the aforementioned engraving of two anthropomorphic figures is placed (Fig. 19). Although the nature and context of the discovery itself may indirectly indicate some relationship with the spiritual life of the stronghold's users, the lack of further figural elements on the Radzim vessel does not enable attempts to include them in a wider narrative framework. There is indeed an attempt to identify them with divine dioscuric twins in the literature (Szafrański 1979: 370); however, no strong arguments sustain this view.

\footnotetext{
${ }^{16}$ It is also unique because of the drawing technique: it is stippled, not carved.
} 


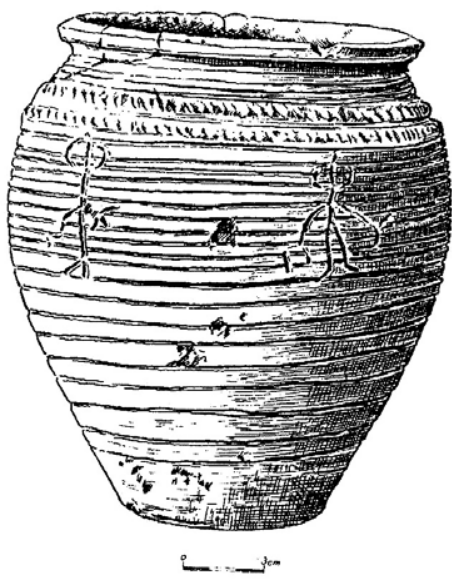

Fig. 19. Radzim. Wielkopolskie, voivodeship, Poland. Ceramic vessel. After Buko 1990: 138, ryc. 63a.

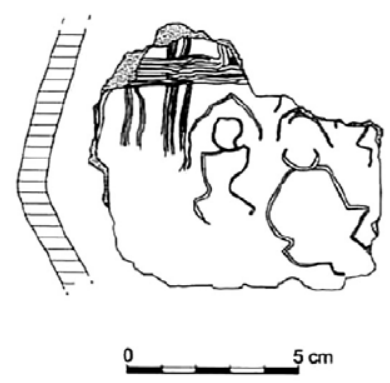

Fig. 20. Repten. Lkr. OberspreewaldLausitz, Germany. Fragment of ceramic vessel. After Kinkeldey 2008, s. 498, Abb. 1:b.

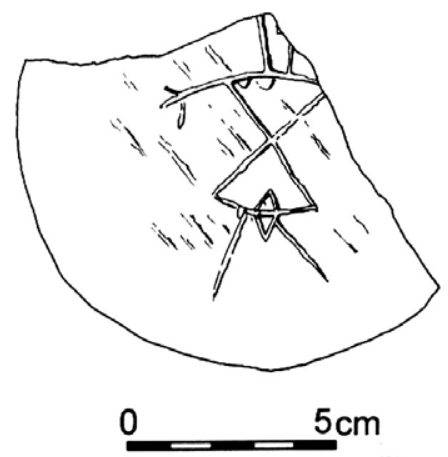

Fig. 21. Nitra. Obr. Nitra, Słovakia. Fragment of ceramic vessel. After Dulinicz 2008: 316, ryc. 5.3.
Similar problems, this time, however, as a result of the incomplete state of drawing preservation, which appears in the case of an iconological analysis of the second piece of ceramics from Polabian Repten (Fig. 20). According to T. Kinkeldey (2008: 499) the incomplete carving shows two schematically marked human figures, and the triangles or semicircles above them, he identifies with raised arms. As the bent "arms" as well as the way of "feet's" expression he interprets as reflecting certain dynamics of the narrative scene. Consequently, we can be dealing with characters shown in movement (thus, these characters are interpreted here as a "group of dancers”) (Biermann 2000: 262, Kinkeldey 2008: 500). The researchers' attention did not escape the pattern preserved in the upper left corner of the vessel's piece, who attempted to identify it as a schematic figure as an animal (horse). In general, the whole scene would show a dancing or kneeling people with arms raised in adoration. However, Kinkeldey indicated yet another way of interpreting the "raised arms" gesture. This element of human figures he identified with masks as a requisite of alleged dancers. However, ultimately the author emphasises that, that due to the fragmentation of depictions, the meaning hidden behind the analysed image cannot be convincingly explained (Kinkeldey 2008: 500).

The final artefact to be discussed was excavated from Nitra in Slovakia. Unfortunately, there is no information about the place and context of its discovery. We can only indicate the chronology of the vessel; it was used between $7^{\text {th }} / 8^{\text {th }}$ and $9^{\text {th }}$ centuries (Dulinicz 2008: 316). The carving shows an anthropomorphic form, whose body was modelled with the help of two triangles touching each other (clepsydra). The figure also clearly shows both legs, one hand with a three-fingers and part of the neck and/or head. An interesting detail is the pair of triangles with touching bases, one of which is placed between the legs, the other slightly higher (Fig. 21). The detail in question and, above all the place of its location in the whole image context, was the basis of gender identification - and thus symbolic - of the figure, 
which were subsequently recognised as female genital organs and as an image of Slavic Alma Mater ("Mother Goddess") (Dulinicz 2008: 316).

However, it seems that the depiction in question can be placed in a broader context of religious symbolism, and not necessarily reducing it to the image of a static figure. I think that in previous attempts to read the meaning hidden behind this depiction, too little attention was paid to the repetition of geometric figures and the meanings associated with them. Researchers of the spiritual culture of the pre-Christian communities have long highlighted the distinct role that some of them played in the imagination of those societies (first of all, including a circle, a triangle, but also a square, penta- or octagon). In all probability, the basis for this predilection should not be sought in geometrical, or - if it can be said - physical features, but in its symbolism (Toporow 1974: 179; Lurker 1989: 253; Kobielus 1997: 39). In the traditional perception (particularly interesting to us here) a triangle was, as it is believed to, a visualisation of the archetypal symbolism of the number three: the tripartite world and the unity of the opposites. Exactly this approach is seen in Indo-European traditions, in which the number three corresponds to the "numerical paradigm of the oldest lunar calendar" (Kolczyński 1996: 95). The number three and its multiple also have a rich symbolism in conceptions of early medieval Slavs. In this context, we can mention even the cosmological competences of Triglav, the triangular stronghold of Svarožic, the number of spears used in the holy horse divination ritual (Arkona, Szczecin), the paradigm of "triple sacrifice" and many others. Space does not permit a detailed description of all these symbols; leaving it for another occasion, we have to indicate the most important conclusions drawn from it, which confirm the important role of this symbolism in the beliefs of Western Slavs.

In our further proceedings decoding the contents carved on the Nitra vessel, we have to recall further arrangements of religious symbolism researchers. This time, they relate to the direct object of our interest, which is the figure of the triangle. It turns out that it codes some values universal to past beliefs. Leaving aside the way the entire discussion on this topic runs, it should be noted that - simplifying the problem - in the symbolic structure, a pointing upwards triangle, associated with the mountain, flame, erection, etc., was seen as a symbol of light, uranic strength, and male reproductive powers. The triangle pointing downwards encoded conflicting meanings: a pit/water reservoir, aquatic element, symbol of telluric/chthonic forces, and also female powers of procreation. All this information provided an extremely interesting tool, which can be used in an attempt to decode the meaning of Nitra vessel depiction. I think, such a characteristic triangle arrangement forming the body of "goddess" (including the way they touch themselves) were an intentionally used, symbolical construct referring to the sphere of religious/mythical narratives. Images not necessarily, or perhaps not only, evoking the archetypal association with the goddess-mother, but a supernatural being focusing its essence on cosmogonic complementarity. That is, one that combined (by itself?) not just the above-mentioned, and seemingly opposite, spheres of activity, but also these elements organising the world order (birth/life/death, morning/day/night, rise/presence/set of the sun, youth/maturity/ old age, heaven/earth/netherworld, etc.). In surviving narratives regarding such a being (interestingly three-headed sometimes), it was described as a "substance" used for the 
construction of world elements (macroanthropos), or a matrix giving rise to the first deities (dioscurs) performing the act of creation (cf. Lincoln 1985; Grzybek 1994; West 2007: 356-359; Konečný 2008: 257). Even though these are just indirect source material, we have some traces that allow us to search for this type of mythical narratives in the religion of early medieval Western Slavs (Gieysztor 1982: 111; Kajkowski 2014). However, research on this problem is still far from satisfactory, which is why the proposed way of reading the image from the Nitra vessel should be considered a hypothesis that requires further verification.

Although the artefacts analysed above belong to an extremely rare cultural phenomenon of the early Middle Ages, ideographically they fit into the group of objects that can be regarded as communicative operators. Analysis of figural visual forms enables presuming that for illiterate communities of this period. they - next to oral tradition - were an important medium of communication between members of communities. (West)Slavic ones were no exception here. Considering this, we should recognise that the figural ornaments appearing on ceramic vessels were not determined by the practical function of the containers themselves. They coded specific socio-cultural information. However, the diversity of decorative type motifs could be related to ceramic forms whose function should be considered directly from the context in which they were used. In this approach, the type of ornament could fulfil the function of a non-aesthetic "source of information between the individuals and the community creating a general framework for information flow" (Bloom 2000; see also Łuczyński 2012; Kowalski 2013: 144). Interesting supplements are provided here by the results of linguistic research, showing the relationships between the oldest vocabulary regarding decoration, ornament and jewellery with the "value of agency resulting from mythical beliefs" (Kowalski 2013: 15).

Unfortunately, only for some of the explored vessels do we have detailed information about the discovery context. Circumstances of findings from Chróścino, Dąbrówka, or Wyszogród, suggest the non-utilitarian nature of the objects in which they were excavated. In the case of Chróścino and Radzim, it is worth emphasising the sizes suggesting a miniature rather, than a full-size container. It is interesting, because they are sometimes considered to be the ceremonial forms of vessels. Specially manufactured for such purposes, they would play a specified function in eschatological, votive or building-offering activities (see Kajkowski 2019: 202-203). In this context, it is also worth mentioning another hypothesis that indicates the problem of intentional barbarisation ${ }^{17}$ of (at least some) the ceramic vessels (Zoll-Adamikowa 1971: 111, 113, Buko 1990: 191-198). The Wyszogród exemplar, referred to Prague-type containers, had such a form. The special function of this vessel can be confirmed by a second, found next to the one in question. There was a sign of the cross engraved at its bottom. In contrast, the U-shaped object, in which these finds were found, was interpreted as a gathering-house (hall), or/and type of warehouse/granary. Both containers have to be a relic of the build-sacrifice (Moszczyński, Szymański 1988: 145).

\footnotetext{
${ }^{17}$ I.e., creating in the technology and style characteristic for vessels dated to the older periods of Middle Ages
} 
It is therefore not excluded, that Kinkedley (2008: 500) was correct, and the vessels decorated with figural scenes were used for religious purposes or/and were of great social significance. Among the latter are the celebrations of the heroic deeds of the stronghold rulers or living/dead or legendary warriors, producing/maintaining/preserving their legend, or other heroic stories. This image, as we had the opportunity to see, should be completed by mythological or ritual scenes, with - essentially - strong accents of zoomorphic symbolism.

Finally, attention should be paid to a quite important detail, generally unnoticed by the researchers dealing with the problem of our interest: the chronology of recent discoveries. Unfortunately, some of these findings are quite general and based on an imperfect method of analysing the ceramic materials. Nevertheless, these are sufficient to draw extremely interesting conclusions. It turns out that as many as 14 of the vessels analysed here were produced in the earliest stages of the Middle Ages (from $6^{\text {th }} / 7^{\text {th }}$, through $7^{\text {th }} / 8^{\text {th }}$ to the $9^{\text {th }}$ centuries), and the vast majority were found in the Baltic Slavs' territory. From the end of $9^{\text {th }}$ / beginning $10^{\text {th }}$ century, we know only three exemplars so far, whereas the youngest (and the most realistic one) comes from the $12^{\text {th }}$ century.

If the interpretative suggestions proposed here are correct, and the engravings on the vessels illustrate religious events, the oldest ones would prove the presence of an extensive belief/mythological sphere not just since the Slavs appearance in the historical arena, but also a "core" of these beliefs common to all Slavic communities. Until now, we had only one source confirming such guesses - the famous passus known from the Prokopius of Caesarea (VII,14) work. This passus applies, as we believe today, an Eastern Slavic society.
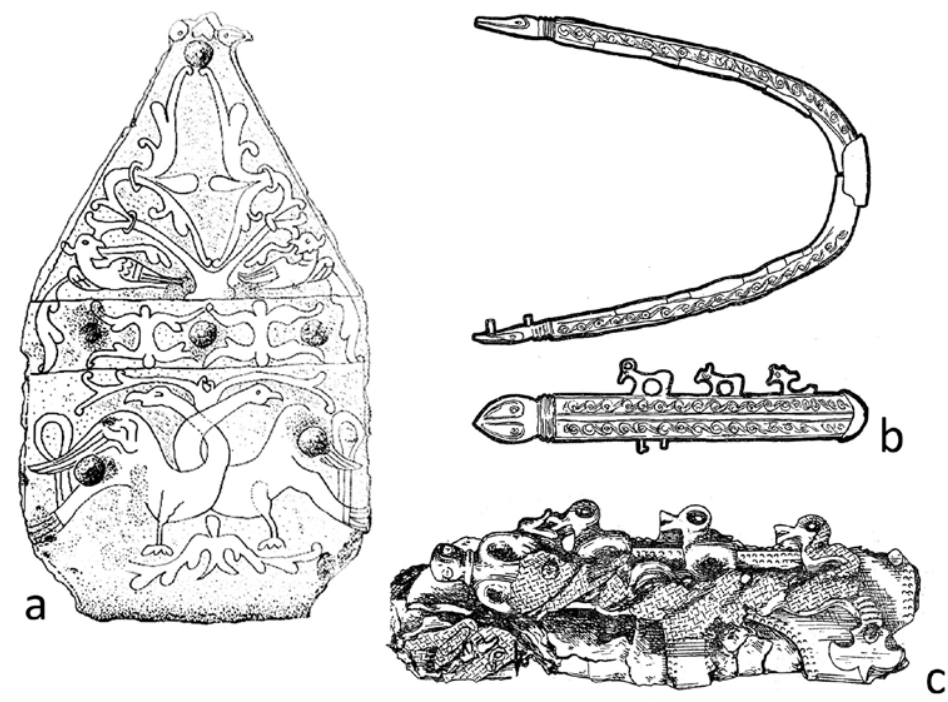

Fig. 22. Zoomorphic figures on Western Slavic elite items: a) Stirrup from Velds, Jutland, Denmark; b) copper-alloy spur from Ciepłe, pomorskie voivodeship, Poland; c) copper-alloy knife sheath, Brześć Kujawski, kujawsko-pomorskie voivodeship, Poland. After Gardeła, Kajkowski in print. 
Also interesting is another conclusion derived from the chronological analysis, which seems to show that vessels decorated with narrative scenes disappeared around the mid- $11^{\text {th }}$ century, which is surprisingly coincident with the moment of socio-political changes in north-eastern Europe observed in this time, which resulted in the formation of centralised power organisms (the so-called early states). These processes were also accompanied by significant changes in the religious field, resulting in the institutionalisation of this sphere of public life. Therefore, it would seem that the disappearance of the production of ceramic vessels, decorated with traditional religious motifs, was a direct result of these transformations. However, this is an apparent conclusion in the context of still pagan in $12^{\text {th }}$ century Baltic Slavs, as well as the lands under the rule of Piast dynasty until the $11^{\text {th }}$ century. Apart from the results of research pointing to the traces of pre-Christian rituals (see Kajkowski in print a), something else is noteworthy. In the mid-1 $1^{\text {th }}$ century, we can observe an intensification of the appearance of pre-Christian mythological ideograms on objects related to the elites of that time (Fig. 22). At this stage of research, it is difficult to indicate whether the observed process was associated with a manifestation of elite identity (based on recent ideological system) forced to confront the new political order supported by Christianity, which could upset their status quo. Perhaps the need for cultural identification referred to the "primordial" origo gentis, legitimising (by religion) the social and perhaps religious position. Research on this issue is ongoing (Gardeła, Kajkowski, Söderberg 2019; Gardeła, Kajkowski, in print; Kajkowski in print b).

The similarity of figurative images known from vessels with later various items depictions enables speculation regarding the duration of at least some of the belief motifs. However, their function was rather different, which was due to the nature of the items on which they were placed. If jewellery, equestrian/military equipment played mainly prestigious/identifying role (but it may also be ceremonial), the ceramic vessels discussed in this text could be used as requisites for ritual activities, but precisely what function they performed is impossible to state indisputably.

\section{REFERENCES}

Abramowicz, Andrzej, 1954: Sztuka rybaków i rzemieślników gdańskich XI-XIII w., Polska Sztuka Ludowa 8/6, Warszawa, 323-353.

Aldhouse Green, Miranda, 2005: An Archaeology of Images. Iconology and cosmology in Iron Age and Roman Europe, London-New York: Routledge.

Alloa, Emmanuel, 2015: Could Perspective ever be a symbolic Form? Revisiting Panofsky with Cassirer, Journal of Aesthetics and Phenomenology 2/1, Oxford, 51-72.

Antosik, Grzegorz; Łuczyński, Michał (eds.), 2020: Badania nad wierzeniami Stowian. Wczoraj, dziś, jutro, Owidz: Stowarzyszenie Ekologiczno-Kulturalne „Wspólna Ziemia”.

Barford, Paul; Marczak, Ewa, 1992: Peasant households, potters and phasing: Early Medieval ceramics from Podebłocie, Poland, Archeologia Polona 30, Warszawa, 127-149.

Barrowclough, David, 2014: Making the Past: Prospective Memoralization and the Creation of Myth, Visual Culture in Britain 15/2, Abingdon, 141-152. 
Biegeleisen, Henryk, 1929: Śmierć w obrzędach, zwyczajach i wierzeniach ludu polskiego, Warszawa: Dom Książki Polskiej.

Biermann, Felix, 2000: Slawischer Besiedlung zwischen Elbe, Neiße und Lubsza, Bonn: Verlag Dr. Rudolf Habelt GmbH (Schriften zur Archäologie der germanischen und slawischen Frühgeschichte, Band 5).

Bonowska, Magdalena, 2008: Przemijajac, pozostaje... Zbiór prac wszystkich, Poznań: Wydawnictwo Eco.

Brzozowska-Krajka, Anna, 1994: Symbolika dobowego cyklu powszedniego w polskim folklorze tradycyjnym, Lublin: UMCS.

Bugaj, Ewa, 2012: Archeologia i sztuka: Tabaczyński, Stanisław; Marciniak, Arkadiusz; Cyngot, Dorota; Zalewska, Anna (eds.), Przeszłość społeczna. Próba konceptualizacji, Poznań: Wydawnictwo Poznańskie, 885-909.

Boom, van den, Helga, 2000: Keramik als Bedeutungsträger. Van den Boom, Helga; Kowalski, Andrzej Piotr; Kwapiński Marian (eds.), Eidolon. Kultura archaiczna w zwierciadle wyobrażeń, słów i rzeczy, Gdańsk: Muzeum Archeologiczne w Gdańsku, 123-136.

Buko, Andrzej, 1988: Elementy symboliczne ceramiki wczesnopolskiej. Problemy analizy. Kobyliński, Zbigniew; Lichy, Bogdan; Urbańczyk, Przemysław (eds.), Myśl przez pryzmat rzeczy, Warszawa: IAiE PAN, 97-105.

Buko, Andrzej, 1990: Ceramika wczesnopolska. Wprowadzenie do badań, Wrocław-WarszawaKraków-Gdańsk-Łódź: Zakład Narodowy im. Ossolińskich, Wydawnictwo PAN.

Buko, Andrzej, 2005: Archeologia Polski wczesnośredniowiecznej. Odkrycia - hipotezy - interpretacje, Warszawa: Trio.

Buko, Andrzej, 2016: 1050-lecie chrześcijaństwa na ziemiach polskich. Państwo Mieszka I i problem wczesnej chrystianizacji Polski w perspektywie badań archeologicznych, Nauka 2, Warszawa, 7-38.

Bylina, Stanisław, 1993: Słowiański świat zmarłych u schyłku pogaństwa. Wyobrażenia przestrzenne, Kwartalnik Historyczny 4, Warszawa, 73-88.

Cassirer, Ernst, 1953: Language and Myth, New York: Dover Publications Inc.

Chudziak, Wojciech, 2015: Rzeki w krajobrazie przyrodniczo-kulturowym wczesnośredniowiecznych Słowian pomorskich. Moździoch, Sławomir; Chrzan, Krystian (eds.), O rzece i wodzie w życiu codziennym człowieka średniowiecza, Wrocław: IAiE PAN.

Cooper, Jean Campbell, 1998: Zwierzęta symboliczne i magiczne, Poznań: Dom Wydawniczy Rebis.

Czarnowski, Stefan, 1956: Dzieła, t. 1, Warszawa: Dom Wydawniczy PWN.

Czerny, Adolf, 1896: Istoty mityczne Serbów Łużyckich (ciąg dalszy), Wisła 10/1, Warszawa, 54-97.

Czerny, Adolf, 1896: Istoty mityczne Serbów Łużyckich (ciąg dalszy), Wisła 10/3, Warszawa, 245-281.

Davison, Jane, 2009: Icon, iconography, iconology. Visual branding, banking and the case of the bowler hat, Accounting, Auditing \& Accountability Journal 22/6, Bungley, 883-906.

Dalewski, Zbigniew, 1990: Zakładziny: obrzęd i mit. O słowiańskich zwyczajach i wierzeniach związanych z budową domu i zakładaniem miasta, Polska Sztuka Ludowa 44/4, Warszawa, 17-24.

Dulinicz, Marek, 2001: Kształtowanie się Stowiańszczyzny Pótnocno-Zachodniej. Studium archeologiczne, Warszawa: IAiE PAN.

Dulinicz, Marek, 2008: Sztuka i mit. Przedstawienia narracyjne na wczesnosłowiańskich naczyniach. Gediga, Bogusław; Piotrowski, Wojciech (eds.), Sztuka pradziejowa i wczesnośredniowieczna jako źródło historyczne, Biskupin-Wrocław: IAiE PAN, 309-322. 
Dulinicz, Marek; Moszczyński, Waldemar Andrzej, 2013: Die ältere slawische Besiedlung des mitteleren Weichsellaufs im Lichte der naturwisenschaftlichen Datierungen. Dulinicz, Marek; Moździoch, Sławomir (eds.), The Early Slavic Settlement in Central Europe in the Light of the New Dating Evidence, Wrocław: IAiE PAN, 53-71.

Duvignaud, Jean, 2010: Ceremonia społeczna i ceremonia teatralna. Kolankiewicz, Leszek (ed.), Antropologia widowisk. Zagadnienia i wybór tekstów, Warszawa: Wydawnictwo UW, 213-218.

Dźwigoł, Renata, 2004: Polskie ludowe stownictwo mitologiczne, Kraków: Wydawnictwo Naukowe Akademii Pedagogicznej.

Eliade, Mircea, 1993: Kowale i alchemicy, Warszawa: Fundacja Aletheia.

Eliade, Mircea, 2001: Szamanizm i archaiczne techniki ekstazy, Warszawa: PWN.

Eliade, Mircea, 2002: Od Zalmoksisa do Czyngis-chana, Warszawa: PWN.

Filipowiak, Władysław, 1993: Słowiańskie wierzenia pogańskie u ujścia Odry. Kwapiński, Marian; Paner, Henryk (eds.), Wierzenia przedchrześcijańskie na ziemiach polskich. Materiały z Sesji Archeologicznej zorganizowanej przez Muzeum Archeologiczne w Gdańsku w dniach 15-16 101987 roku, Gdańsk: Muzeum Archeologiczne w Gdańsku, 19-46.

Fischer, Adam, 1921: Zwyczaje pogrzebowe ludu polskiego, Lwów: Zakład Narodowy im. Ossolińskich.

Forstner, Dorothea, 1990: Świat symboliki chrześcijańskiej, Warszawa: Instytut Wydawniczy PAX.

Friis-Jensen, Karsten (ed.), 2015: Saxo Grammaticus Gesta Danorum - The History of the Danes, Oxford: Clarendon Press.

Gardeła, Leszek; Kajkowski, Kamil, in print: Slavs and Snakes: Material Markers of Elite Identity in Viking Age Poland, European Journal of Archaeology

Gardeła, Leszek; Kajkowski, Kamil; Ratajczyk, Zdzisława, 2019: Ostrogi zoomorficzne z Ciepłego. Zachodniosłowiański model kosmosu?, Pomorania Antiqua 28, Gdańsk, 65-52.

Gardeła, Leszek; Kajkowski, Kamil; Söderberg, Bengt, 2019: The spur goad from Skegrie in Scania, Sweden. Evidence of the elite interaction between Viking Age Scandinavians and Western Slavs, Fornvännen 114/2, 2019, Stockholm, 57-74.

Gieysztor, Aleksander, 1982: Mitologia Stowian, Warszawa: Wydawnictwo Artystyczne i Filmowe.

Gładyszowa, Maria, 1960: Wiedza ludowa o gwiazdach, Wrocław: Ossolineum.

Glob, Peter Vilhelm, 2004: The Bog People. Iron-Age Man Preserved, New York: New York Review Books.

Grzybek, Peter, 1994: The culture of nature. The semiotic dimensions of microcosm, mesocosm, and macrocosm. Nöth, Winfried (ed.), Origins of Semiosis. Sign Evolution in Nature and Culture, Berlin-New York: de Gruyter, 121-138.

Gustavs S., 1979: Frühslawisches Gefässfragment mit Darstellung einer kultischen Szene von Schulzendorf, Kr. Königs Wüsterhausen, Zeitschrift für Archäologie 13, Berlin, 279-292.

Hensel, Witold, 1984: Skad przybyli Stowianie?, Wrocław: Wydawnictwo Stronnictwa Demokratycznego.

Hołubowicz, Włodzimierz, 1956: Opole w wiekach X-XII, Katowice: Wydawnictwo Śląsk.

Janowski, Andrzej; Kurasiński, Tomasz, 2008: (Nie)militarne naczynia. Fakty i mity: Świętosławski, Witold (ed.), Nie tylko broń. Niemilitarne wyposażenie wojowników w starożytności $i$ średniowieczu, Łódź: Łódzkie Towarzystwo Naukowe. 
Jasnosz, Stanisław, 1982/1984: Materiały i studia do dziejów osadnictwa starożytnego i wczesnośredniowiecznego Ziemi Obornicko-Rogozińskiej, Fontes Archaeologici Posnaniensis 33, Poznań, 55-166.

Kajkowski, Kamil, 2014: Znaczenie odciętych głów w obrzędowości pogańskiej wczesnośredniowiecznych Słowian zachodnich, Studia Mythologica Slavica 17, Ljubljana, 135-153.

Kajkowski, Kamil, 2016: Słowiańskie (?) pochówki w łodziach. Rozważania nad aspektami obrzędowości pogrzebowej wczesnośredniowiecznych Słowian Zachodnich. Franz, Maciej; Kościelniak, Karol; Pilarczyk, Zbigniew (eds.), Śmierć w dziejach człowieka. Starożytność i średniowiecze, Toruń: Adam Marszałek, 43-80.

Kajkowski, Kamil, 2019: Obrzędowość religijna Pomorzan we wczesnym średniowieczu. Studium archeologiczne, Wrocław: Chronicon.

Kajkowski, Kamil, in print a: „Kryzys monarchii piastowskiej” a problem tzw. reakcji pogańskiej, book to be published.

Kajkowski, Kamil, in print b: Na pograniczu polityki i religii. O potencjalnej (samo)identyfikacji wczesnośredniowiecznych elit Słowiańszczyzny Północno-Zachodniej, book to be published.

Kalinowski, Daniel, 2016: Polacy-Słowianie - pomiędzy geopolityką a geopoetyką. Kalinowski, Daniel; Foltyn, Edyta (ed.), Kulturowe projekcje Stowian w tradycji polskiej, Słupsk: Akademia Pomorska w Słupsku, 15-34.

Kara, Michał, 2009: Najstarsze państwo Piastów - rezultat przełomu czy kontynuacji? Studium archeologiczne, Poznań: IAiE PAN.

Kinkeldey, Thomas, 2008: Figürliche Darstellungen auf mittelslawischer Keramik vom Brugwall Repten bei Calau. Biermann, Felix. Müller, Uwe. Terberger, Thomas (eds.), „,Die Dinge beobachten ... ". Archäologische und historische Forschungen zur frühen Geschichte Nordund Mitteleuropas, Rahden: VML Vlg Marie Leidorf, 497-501.

Kobielus, Stanisław, 1997: Człowiek i ogród rajski w kulturze religijnej średniowiecza, Warszawa: Instytut Wydawniczy PAX.

Kolczyński, Jarosław, 1996: Trójnożna koza. Uwagi o symbolice trójnożności, Etnografia Polski 40/1-2, Warszawa, 81-107.

Kolendo, Jerzy (ed.), 2008: Tacyt, Germania, Poznań: Wydawnictwo Naukowe UAM.

Kollinger, Karol, 2014: Polityka wschodnia Bolestawa Chrobrego (992-1025), Wrocław: Chronicon.

Konečný, Lubomír, 2008: The Myth of the Spring New Year and the Time-Space of the Calendar Year as "imago mundi" in the Romanesque Paintings of the Rotunda in Znojmo (Moravia). Mencej, Mirjam (ed.), Space and Time in Europe: East and West, Past and Present, Ljubljana: Zupaničeva knjižnica, 249-271.

Kotowicz, Piotr, 2013: The Sign of the Cross on the Early Medieval Axes - a Symbol of Power, Magic or Religion? Marek, Lech (ed.), Weapons Brings Peace? Warfare in Medieval and Early Modern Europe, Wrocław: Instytut Archeologii UWr, 41-55.

Kowalczyk, Małgorzata, 1968: Wierzenia pogańskie za pierwszych Piastów, Łódź: Wydawnictwo Łódzkie.

Kowalski, Andrzej Piotr, 2007: Klasyfikacja działań wytwórczych w kulturze indoeuropejskiej. Bednarczuk, Arkadiusz. Bugaj, Ewa. Rządek, Wiesław (eds.), Eurazja i antyk, Poznań: Wydział Archeologii UAM, 155-162.

Kowalski, Andrzej Piotr, 2008: Kulturoznawcza genealogia kategorii materialności rzeczy. Kowalewski, Jacek; Piasek, Wojciech; Śliwa, Marta (eds.), Rzeczy i ludzie. Humanistyka wobec materialności, Olsztyn: Instytut Filozofii UWM w Olsztynie, 15-26. 
Kowalski, Andrzej Piotr, 2013: Mit a piękno. Z badań nad pochodzeniem sztuki, Bydgoszcz: Oficyna Wydawnicza Epigram.

Kóčka-Krenz, Hanna, 1998: The Northwestern Slavonic Finger-Rings of Orszymowice Type in the Early Middle Ages. Wesse, Anke (ed.), Studien zur Archäologie des Ostseeraumes. Von der Eisenzeit zum Mittelalter. Festschrift für Michael Müller-Wille, Neumünster: Wachholtz Verlag, 555-560.

Kropej, Monika, 2008: Slovene Midwinter. Deities and Personifications of Days in the Yearly, Work, and Life Cycles. Mencej, Mirjam (ed.), Space and Time in Europe: East and West, Past and Present, Ljubljana: Zupaničeva knjižnica, 181-197.

Kropej, Monika, 2012: Supernatural Beings from Slovenian Myth and Folktales, Ljubljana: Scientific Research Centre of the Slovenian Academy of Sciences and Arts.

Kunicka-Okuliczowa, Łucja, 1959: Wczesnośredniowieczne zabawki i gry z Gdańska. Kamińska, Janina (ed.), Gdańsk wczesnośredniowieczny, t. 1, Gdańsk: Gdańskie Towarzystwo Naukowe, 107-143.

Kurasiński, Tomasz, 2018: Razem czy osobno? Naczynia drewniane i gliniane na cmentarzyskach doby wczesnopiastowskiej. Nowakiewicz, Tomasz; Trzeciecki, Maciej; Błaszczyk, Dariusz (eds.), Animos labor nutrit. Studia ofiarowane Profesorowi Andrzejowi Buko w siedemdziesiata rocznice urodzin, Warszawa: IAiE PAN, 247-270.

Lang, Karen, 2006: Chaos and Cosmos: On the Image in Aesthetics and Art History, Ithaca: Cornell University Press.

Lepówna, Barbara, 1959: Wczesnośredniowieczne znaki garncarskie ze stanowiska 1 w Gdańsku. Kamińska, Janina (ed.), Gdańsk wczesnośredniowieczny, t. I, Gdańsk: Gdańskie Towarzystwo Naukowe, 29-54.

Lepówna, Barbara, 1968: Garncarstwo gdańskie w X-XIII wieku, Gdański: Gdańskie Towarzystwo Naukowe

Limisiewicz, Aleksander, 2002: Kulturowe aspekty inhumacji na Śląsku w dobie przedpiastowskiej. Wrzesiński, Jacek (ed.), Popiół i kość, Sobótka-Wrocław: Muzeum Ślężańskie im. S. Dunajewskiego w Sobótce, AKME Zdzisław Wiśniewski, 353-360.

Lincoln, Bruce, 1985: Of Meat and Society, Sacrifice and Creation, Butchers and Philosophy, L'Uomo 9/1-2, Rome, 9-29.

Lurker, Manfred, 1989: Słownik obrazów i symboli biblijnych, Poznań: Pallotinum.

Łęga, Władysław, 1929: Kultura Pomorza we wczesnem średniowieczu na podstawie wykopalisk, cz. I, Roczniki Towarzystwa Naukowego w Toruniu 35, Toruń, 153-446.

Łuczyński, Michał, 2012: Semantyka obrzędów wiosennych związanych z Marzanną i Jaryłą (próba rekonstrukcji ,prasłowiańskiego tekstu”), Respectus Philologicus 10, Kraków, 165-176.

Łuka, Leon Jan, 1973: Wierzenia pogańskie na Pomorzu Wschodnim w starożytności i we wczesnym średniowieczu, Wrocław-Warszawa-Kraków-Gdańsk: Polska Akademia Nauk.

Łukaszyk, Agnieszka, 2012: Wierzchowce Bogów. Motyw konia w wierzeniach Słowian i Skandynawów, Szczecin: Triglav.

Małecki, Rafał, 1995: Magiczno-religijna funkcja starożytnych wozów, Archeologia Polski 40/1-2, Warszawa, 91-105.

Mamzer, Henryk, 2018: Od „socjologii ceramicznej” po procesy urbanizacyjne i państwotwórcze. Archeologia Andrzeja Buko i jej konsekwencje interpretacyjne. Nowakiewicz, Tomasz; Trzeciecki, Maciej; Błaszczyk, Dariusz (eds.) Animos labor nutrit. Studia ofiarowane Profesorowi Andrzejowi Buko w siedemdziesiata rocznicę urodzin, Warszawa: IAiE PAN, 39-46. 
Masłowska, Ewa; Niebrzegowska, Stanisława, 1999: Rzeka. Bartmiński, Jerzy (eds.), Stownik stereotypów i symboli ludowych, t. 1: Kosmos, Lublin: Wydawnictwo UMCS, 324-350.

Messal, Sebastian, 2015: Glienke. Eine slawische Burg des 9. und 10. Jahrhunderts im östlichen Mecklenburg, Wiesbaden: L. Reichert (Frühmittelalterliche Archäologie zwischen Ostsee und Mittelmeer, Band 5).

Mieletinski, Eleazar, 2009: Pochodzenie eposu bohaterskiego. Wczesne formy i archaiczne zabytki, Kraków: Nomos.

Mikoś, Kazimiera, 1997: Boginie deszczu. Studium porównawcze, Kraków: Wydawnictwo UJ.

Müller, von, Adrian; Müller-Muči, von, Klara, 1998: Ausgrabungen und Funde auf dem Burgwall in Berlin-Spandau, Berlin: Spiess Volker GmbH.

Panfil, Tomasz, 2002: Lingua symbolica. O pochodzeniu i znaczeniach najstarszych symboli heraldycznych $w$ Polsce, Lublin: KUL.

Pankalla, Andrzej Bronisław, Kośnik, Konrad Kazimierz, 2018: Indygeniczna psychologia Stowian. Wprowadzenie do realnej nauki o duszy, Kraków: Universitas.

Panofsky, Erwin: 1939: Studies in Iconology: Humanistic Themes in the Art of the Renaissance, New York: Oxford University Press.

Pawlak, Ewa; Pawlak, Paweł, 2019a: Charakterystyka ceramiki wczesnośredniowiecznej na stanowisku 2 w Dąbrówce. Szmyt, Marzena; Pawlak, Paweł (eds.), Dwa grody nad Wirynkq. Dąbrówka, stanowiska 1 i 2, woj. wielkopolskie, Poznań: Muzeum Archeologiczne w Poznaniu, 173-324.

Pawlak, Ewa; Pawlak, Paweł, 2019b: Przejawy życia duchowego mieszkańców grodu na stanowisku 2 w Dąbrówce. Szmyt, Marzena; Pawlak, Paweł (eds.), Dwa grody nad Wirynka. Dabrówka, stanowiska 1 i 2, woj. wielkopolskie, Poznań: Muzeum Archeologiczne w Poznaniu, 163-172.

Planert, Martin, 2012: Die slawische Keramik vom Burgberg Lenzen. Biermann, Felix; Kersting, Thomas; Klammt, Anne; Westphalen, Thomas (eds.), Transformationen und Umbrüche des 12./13. Jahrhunderts Beiträge der Sektion zur slawischen Frühgeschichte der 19. Jahrestagung des Mittel- und Ostdeutschen Verbandes für Altertumsforschung in Görlitz, 01. bis 03. März 2010, Langenweissbach: Beier \& Beran, 311-321.

Polek, Krzysztof, 2017: Historiografia o misjach chrześcijańskich na ziemiach polskich przed 966 rokiem. Dobosz, Józef; Matla, Marzena; Strzelczyk, Jerzy (eds.), Chrzest Mieszka I $i$ chrystianizacja państwa Piastów, Poznań: Wydawnictwo Naukowe UAM, 27-60.

Pollington, Stephen, 2013: The Stag in Anglo-Saxon Tradition: Mortimer, Paul; Pollington, Stephen (eds.), Remaking the Sutton Hoo Stone. The Ansell-Roper Replica and its Context, Little Downham: Anglo Saxon Books, 109-116.

Poniatowski, Zygmunt, 1962: Wstęp do religioznawstwa, Warszawa: Wiedza Powszechna.

Schmitt, Jean-Claude, 2002: Duchy. Żywi i umarli w społeczeństwie średniowiecznym, Gdańsk-Warszawa: Marabut.

Shenk, Peter, 2002: To Valhalla by Horseback? Horse Burial in Scandinavia during the Viking Age, unpublished $\mathrm{PhD}$ (archives of The Center for Viking and Medieval Studies, The Faculty of Art, University of Oslo).

Sikorski, Andrzej, 1991: Ryt figuralny i aplikacja plastyczna na wczesnośredniowiecznej ceramice naczyniowej z Dębczyna, woj. Koszalin, Sprawozdania Archeologiczne 43, Warszawa, 281-287.

Szafrański, Włodzimierz, 1979: Pradzieje religii w Polsce, Warszawa: Iskry. 
Szczepanik, Paweł, 2015: Wojenne wyprawy Świętowita. Mit i jego materialne przedstawienie. Franz, Maciej; Kościelniak, Karol; Pilarczyk, Zbigniew (eds.) Migracje. Podróże w dziejach. Starożytność i średniowiecze, Toruń: Adam Marszałek, 175-188.

Szyjewski, Andrzej, 2003: Religia Stowian, Kraków: Nomos.

Szymański, Wojciech; Moszczyński, Waldemar Andrzej, 1988: Ryt perunowy (?) z Wyszogrodu, Z Otchłani Wieków 53, Warszawa, 140-145.

Tanner, Jeremy, 2006: The Invention of Art History in Ancient Greece, Cambridge: Cambridge University Press.

Toporow, Wladimir, 1974: O modelach liczbowych w kulturach archaicznych, Teksty. Teoria literatury, krytyka, interpretacja 1, Warszawa, 167-188.

Vańa, Zdenek, 1999: Mythologie und Götterwelt der slawischen Völker. Die geistigen Impulse Osteuropas, Stuttgart: Urachhaus/Geistesleben.

Wachowski, Krzysztof, 1975: Cmentarzyska doby wczesnopiastowskiej na Śląsku, Wrocław: Zakład Narodowy im. Ossolińskich.

Waida, Manbu, 2005: Birds. Jones, Lindsay; Eliade, Mircea; Adams, Charles (eds.), Encyclopedia of Religion, Detroit: McMillan, 947-951.

West, Martin, 2007: Indo-European Poetry and Myth, Oxford: Oxford University Press.

Wietrzichowski, Frank, 1990: Zur Verbreitung und Entwicklung der Sukower Gruppe in Mecklenburg, Bodendenkmalpflege in Mecklenburg-Vorpommern Jahrbuch 1989, Berlin, 37-102.

Wittkower, Rudolf, 1990: Interpretacja symboli wizualnych. Głowiński, Michał (ed.), Symbol $i$ symbolika, Warszawa: Czytelnik, 339-357.

Woźny, Jacek, 2017: Symbolika i magia żywiołu wody w światopoglądzie archaicznym. Fudziński, Mirosław; Świętosławski, Witold; Chudziak, Wojciech (eds.), Pradoliny pomorskich rzek. Kontakty kulturowe $i$ handlowe społeczeństw w pradziejach $i$ wczesnym średniowieczu, Gdańsk: Muzeum Archeologiczne w Gdańsku, 27-35.

Zdybicka, Zofia, 1993: Człowiek i religia. Zarys filozofii religii, Lublin: Towarzystwo Naukowe KUL.

Zoll-Adamikowa, Helena, 1971: Wczesnośredniowieczne cmentarzyska szkieletowe Małopolski, cz. II. Analiza, Wrocław-Warszawa-Kraków-Gdańsk: PAN. 


\section{MIT W AKCJI? RYTY FIGURALNE NA CERAMICE JAKO ŹRÓDŁO DO BADANIA PRZEDCHRZEŚCIJAŃSKICH WIERZEŃ SŁOWIAN ZACHODNICH.}

KAMIL KAJKOWSKI

$\infty \infty$

Badania nad kulturą duchową Słowian Zachodnich, mimo sceptycyzmu niektórych badaczy, przeżywają w ostatnich latach wyraźny postęp. Dzieje się tak m.in. dzięki dynamicznemu przyrostowi źródeł wykopaliskowych oraz rozwojowi archeologii jako dziedziny naukowej. Dziedziny, której przedstawiciele coraz pewniej zawierają głos w kontekście pozostałości dawnych wierzeń, rewaluując lub formułując szereg hipotez pozwalających na poszerzenie dotychczasowej wiedzy. Ważną rolę odgrywają tutaj zarówno studia nad reliktami miejsc kultu czy aktów obrzędowych, ale również badania materialnych wytworów kultury w tym czynności podejmowanych z chwilą ich produkcji, funkcji, formy czy w końcu ornamentyki. Badania te dotyczą nie tylko na ogół niezwykle atrakcyjnych elementów kultury ówczesnych elit, ale także najbardziej powszechnych rodzajów przedmiotów wydobywanych z ziemi, w tym najbardziej masowych źródeł, jakimi są naczynia ceramiczne. Zdziwienie może wzbudzać fakt, że mimo wyjątkowo rzadko występujących okazów zdobionych wątkami figuralnymi, nie doczekały się one dotąd zbyt wielu prób interpretacji. Prace poświęcone temu problemowi policzyć można na palcach rąk, a próbę całościowego ujęcia omawianych wątków podjął właściwie Marek Dulinicz poświęcając im nieco uwagi w szerokim kontekście kultury materialnej Słowian Zachodnich (2001) a siedem lat później odrębne studium. Od ostatniego wystąpienia tego badacza w 2008 roku, brak nowej refleksji nad tym zagadnieniem. Mimo iż zasób znanych dziś całych lub fragmentów naczyń z rytami figuralnymi uległ poszerzeniu, to wciąż w małym tylko stopniu dotyczy to scen narracyjnych. Liczba takich motywów zdobniczych nadal przyrasta bardzo wolno, co - biorąc od uwagę intensyfikację poszukiwań archeologicznych, stawia je na pozycji źródeł bardzo rzadkich i wyjątkowych. Do podjętych w niniejszym tekście analiz wytypowano blisko dwadzieścia zabytków, z czego większość to mniejsze lub większe fragmenty naczyń. Tylko w dwóch przypadkach pojemniki wydobyte zostały w całości. Oba można też zaliczyć do egzemplarzy małych rozmiarów. Niemal wszystkie (za wyjątkiem skorupy z Nitry) pochodzą z badań prowadzonych na obszarze Słowiańszczyzny Północno-Zachodniej, choć najliczniejszą grupę reprezentują zabytki z jej nadbałtyckiej części (Połabie i Pomorze). Po dwa egzemplarze znaleziono na Mazowszu i na Śląsku. Analiza ustaleń chronologicznych pozwoliła określić, że najczęściej pojawiały się one w nawarstwieniach datowanych od VI do IX w., zanikając około XI stulecia. Jest to zaskakująco zbieżne z momentem zmian społeczno-politycznych jakie obserwujemy w tym czasie w Europie Północno-Wschodniej. Zmian, które w rezultacie doprowadziły do wykształcenia zwartych organizmów o scentralizowanej 
władzy (tzw. wczesnych państw). Procesom tym towarzyszyły także znamienne zmiany na polu religijnym dążące do instytucjonalizacji tej sfery życia publicznego. Wydawałoby się, że zanik produkcji naczyń zdobionych tradycyjnymi wątkami religijnymi był bezpośrednim wynikiem tych transformacji. Wygląda jednak na to, że jest to zależność pozorna. I to nie tylko w kontekście Połabia $\mathrm{i}$ Pomorza, pogańskich do XII w. ale także ziem do XI stulecia objętych władzą Piastów. Pomijając wyniki badań archeologicznych wskazujących na datowane na ten okres ślady miejsc kultu i/lub obrzędowości przedchrześcijańskiej warto tu zwrócić uwagę na coś jeszcze. Okazuje się bowiem, że właśnie od połowy XI w. obserwujemy wyraźną intensyfikację umieszczania przedchrześcijańskich ideogramów - zapewne o treściach religijnych/mitologicznych - na przedmiotach o charakterze elitarnym. Na tym etapie badań trudno wskazać, czy zaobserwowany proces wiązał się z chęcią manifestacji przekonań arystokracji zmuszonej do konfrontacji z nowym, podpartym chrześcijaństwem, porządkiem politycznym, czy może z potrzebą identyfikacji kulturowej odwołującej się do „odwiecznej” origo gentis sakralnie legitymizującego zajmowaną pozycję społeczną a zapewne i religijna. Podobieństwo wyobrażeń figuralnych znanych z naczyń ceramicznych oraz późniejszych zabytków elitarnych pozwala domyślać się trwałości przynajmniej niektórych wątków wierzeniowych, choć różna była ich funkcja, która wynikała $z$ samego już charakteru przedmiotów, na których je umieszczano. I jeśli elementy biżuterii, oporządzenia jeździeckiego czy militaria odgrywały zadana głównie prestiżowe/identyfikacyjne (ale niewykluczone że także obrzędowe), to omawiane w tym tekście naczynia ceramiczne mogły być wykorzystywane jako rekwizyty do działań kultowych, choć jaką dokładnie spełniały funkcję nie sposób bezdyskusyjnie stwierdzić. Nie mamy też pewności jakie wydarzania miały „opisywać: ryty umieszczone na powierzchni naczyń ceramicznych. Najczęstszym motywem figuralnym jaki obserwujemy na zachowanych zabytkach są wyobrażenia zwierząt, wśród których mogły być zarówno konie, jelenie, bydło a nawet gatunki „fantastyczne". W trzech przypadkach zwierzęta były wierzchowcami dosiadanymi przez postaci antropomorficzne. Podobne przypuszczenia wysunięto do czterech kolejnych, choć trudno tu o pewność. Wyłączając jeźdźców, wyobrażenia antropomorficzne znane są z czterech kolejnych zabytków. Fragmentaryczny stan zachowania zdecydowanej większości omawianych rytów nie pozwala pewniej określić wyglądu całej pierwotnej sceny narracyjnej. Jednak zarówno materiał porównawczy (w postaci scen zdobiących inne zabytki), kontekst odnalezienia oraz (choć tylko pośrednio) rzadkość występowania skłoniły mnie do uznania ich za fragmenty scen figuralnych dotyczących wydarzeń religijnych lub mitycznych.

Kamil Kajkowski, Ph.D., Senior Curator, Muzeum Zachodniokaszubskie w Bytowie, ul.Zamkowa 2, 77-100 Bytów, Poland, kamilkajkowski@wp.pl 